\title{
Surrogacy and Islam: Between Permissibility and Prohibition
}

\author{
Tawfique Al-Mubarak*
}

Surrogacy has been a much debated issue from the Shari 'ah perspective since the mid-1980s and is still being discussed. It is generally considered impermissible in Islam. This issue was first addressed at the seventh session of the Muslim World League's Islamic Fiqh Council meeting in 1404 AH/1985 CE, wherein the following year, the Council permitted fertilisation of the zygote only among married couples but with certain conditions. The Council however retracted its earlier views on permitting surrogacy among co-wives of the same husband. ${ }^{1}$ Similarly, the Fiqh Council of the Organization of Islamic Conference (OIC) in 1986 concluded that surrogacy could be permissible only between married couples and under certain conditions. ${ }^{2}$ Despite a restrictive opinion from these two authoritative fiqh councils, some Muslim scholars have also argued in favour of surrogacy, which demands more discussion here.

\section{Is Surrogacy Permissible in Shari'ah?}

Surrogacy is an arrangement when a woman carries in her womb a couple's sperm and ovum to produce a child for the intended parents. Surrogacy is mainly of two types: traditional surrogacy and gestational surrogacy. In traditional surrogacy, the surrogate mother carries her own ovum fertilised by sperm from an intended father. Therefore, the surrogate child is genetically affiliated with the surrogate mother and the intended father. However, in the gestational form of surrogacy both the ovum and the sperm are donated by the intended parents. The surrogate only carries in her womb the donated ovum and the sperm and gives birth to the child. Genetically the child is affiliated to the donors of the ovum and the sperm, but has no relationship with the surrogate "mother".

Although most of the scholars consider surrogacy absolutely unlawful in Islam, there have been a few scholars who advocated it. ${ }^{3}$ They argued that the Qur'anic verses which mention pregnancy ${ }^{4}$ do not necessarily forbid surrogacy. ${ }^{5}$ Secondly, the proponents of surrogacy consider it permissible on the analogy of 'wet-nursing' in Islam. As the foster mother who breastfed the baby and provides nutrition through it, similarly in surrogacy, the baby is nourished by the surrogate mother. Hence they consider no difference between surrogacy and wet-nursing, and the legal ruling for the two should not differ either. 


\section{Impermissibility of Surrogacy: The Evidence}

The main arguments refer primarily to the Qur'anic verses al-Mu'minūn: 5-7, and al-Ma'arij: 29-31 which make it incumbent upon the Muslims to preserve their chastity. ${ }^{6}$ The verses clearly express that insemination of one's semen into the womb of another woman, unless it be his wife, is a violation of the Qur'anic injunction. Similarly, the verse al-Nahl: 72 quotes:

And Allah has made for you mates (and companions) of your own nature, and made for you out of them sons and daughters and grandchildren... ${ }^{7}$

This implies that Allāh s.w.t. created the children through marriage "out of them" - the wives and not out of others (e.g. surrogates), which is a clear sign of the prohibition of surrogacy outside marriage in Islam.

Besides the Qur'anic injunctions, there are also many scientific and rational stances behind such a call for prohibition of surrogacy. First and foremost, there is a high chance for mixing of lineage. The Fiqh Council of the OIC in its earlier meeting earlier validated surrogacy in a polygamous relation, i.e. between cowives where a co-wife provides the ova and the other co-wife carries it as a surrogate mother. After considering several cases, the Council invalidated it even between the co-wives due to high chance of mixing of lineage. For instance, a case was brought to the committee where the surrogate gave birth to twins, and this led to a conflict in determining the lineage of the newborn child. ${ }^{8}$

When considering this from a legal and contractual perspective, it is by nature a void agreement due to the existence of gharar (uncertainty). Gharar is applied to contracts where the products are unknown and there is risk or uncertainty in them. ${ }^{9}$ In this case, there is no guarantee that the surrogate will live until the delivery of the child, or that the child would be healthy and sound, like the case of Judy Stiver and Alexander Malahoff. Malahoff and his wife had an agreement with Judy Stiver to bear a child for them. When the child was born, it was found to have the handicap of 'microcephaly' - having smaller-than-normal head indicating retardation or underdeveloped brain. Both the parents renounced the child. ${ }^{10}$

Furthermore, the child after its birth is highly likely to face a conflict over the relationship between him and the two mothers. Who should she consider as mother, and what role should the other mother play? This could cause serious psychological stress on the child, and on the surrogate mother who carried him during the pregnancy and bonded with the child emotionally and has to face the prospects of relinquishing the child. ${ }^{11}$ Doctors have now suggested that depression is itself a kind of toxic exposure for the foetus. ${ }^{12}$ In surrogacy, the carrier's psychological wellbeing becomes necessary to be taken into account, 
as depression causes great harm to the foetus, which the intended parents would never want. In research by Christina Chambers and her colleagues, it was reported that women dosed with fluexetine during pregnancy are more likely to give birth to infants with three or more minor anomalies at birth. Similar results were found by another group of researchers at Massachusetts General Hospital. Therefore, surrogacy should be considered unacceptable in order to prevent causing greater harm (sadd al-dhari' ah) to the foetus.

The majority of scholars view surrogacy as impermissible, whether paid or voluntary. Paid surrogacy is now common practice in the West but in Islam it is considered a 'greater sin and is of a higher degree of prohibition. ${ }^{13}$ The Shari' ${ }^{-}$ah does not permit the use or rental of private parts and uterus of a person unless there is an explicit Shar ${ }^{\prime} \bar{i}$ evidence to substantiate that. ${ }^{14}$ Since there are no specific textual evidence to permit any such case, surrogacy in general is considered impermissible.

\section{How is Surrogacy Different from Wet-nursing?}

An analysis of the textual evidence from the Qur'ān and the Sunnah clarifies the fundamental difference between the two - surrogacy and wet-nursing. The Qur'ān permits wet-nursing in several verses, such as al-Talāq: 6, and al-Baqarah: 233. Furthermore, siblings nursed by the same wet-nurse are considered illegal for marriages in al-Nisã : 23, which proves the permissibility of wet-nursing, and establishes the milk relationship between those lactated by the same mother. Similarly, the Prophet (peace be upon him) prohibited marriage between the milkrelatives of the same wet-nurse. ${ }^{15}$ All the above-mentioned Qur'anic verses and the hadith prove that wet-nursing is allowed in Sharī'ah, and it also establishes a special relationship among breastfed children and the wet-nurse's families.

On the other hand, those who advocate for surrogacy do not have any established Shar' $\bar{i}$ evidence to support them, except they consider it only on the basis of manfa'ah - that the child is nourished by the surrogate's or the wetnurse's nutrition. However, the analogy of surrogacy with weaning is invalid, as there is no 'illah, or 'cause' for the analogy in this case. Besides, the principles of Islamic jurisprudence do not consider any such manfa'ah contradicting the Sharī'ah, hence such permission for surrogacy cannot be granted. ${ }^{16}$

Above all, in the case of wet-nursing the lineage of the child is well established; while in surrogacy, there is still a high chance for mixing in the lineage. Complications in determining lineage may occur in many variant forms such as in the fertilisation of the donor's sperm with the surrogate's egg instead of the donor's egg; fertilisation of the surrogate's husband's sperm with the donor's egg; or even fertilisation of the donor's husband's sperm with the surrogate's egg. In all of these cases, the lineage of the child cannot be established until 
it is born and DNA test results have proven it. In the case where the intended child does not result, the contract will face severe legal problems with extreme socio-psychological tensions, and ethico-moral implications. Based on the above fundamental arguments, we have to dismiss the claims that surrogacy can be considered permissible on the analogy of wet-nursing.

\section{Notes}

* Tawfique Al-Mubarak is an IAIS Research Fellow with a major interest in topics relating to Shariah issues in Islamic Finance, Maqasid al-Shariah, contemporary fiqh, hiyal, and Islamic microfinance. His work at present, in collaboration with Professor M.H. Kamali and Dr. Farid Ali, is on Shariah Objectives (Maqasid alShariah) in Financial Transactions and Contracts, towards framing a model for an alternative approach to poverty alleviation.

1. Eighth Session of the Islamic Figh Council, held in Makkah Mukarramah, 18 Rabi $^{\mathrm{c}}$ al-Akhir to 7 Jumādā al-Ūla 1405 AH. (19-28 January, 1985), available online: http://www.themwl.org/Fatwa/default.aspx?d=1\&cidi=100\&l=AR\&cid=12, Access date: $20^{\text {th }}$ May, 2010.

2. Islam Q\&A, "Is it permissible to put the sperm of the husband and the egg from the wife in the womb of the second wife?" (n.d.), available from: http://islamqa. info/en/83799, Access date: $4^{\text {th }}$ March, 2014.

3. The proponents of permissibility include Dr. Na'eem Yaaseen. See Ahmad M. Lutfî Ahmad, Al-Talqūh al-Sanā'ì Bayna Aqwāl al-Atibbā wa-Ārā à̈-Fuqahā (Alexandria: Dar al-Fikr al-Jamā'̄i, 2006$), 242$.

4. cf: Mujādilah: 2, al-Naḥl: 78, Luqmān: 14, and al-Ahqāe: 15, etcetera.

5. Ahmad M. Lutfī Ahmad, 254.

6. "And those who guard their chastity, except with their wives ..." al-Mu'minūn: 5-7, and al-Ma'arij: 29-31.

7. al-Nahl: 72

8. Zayad Ahmad Salamah, Atfāl al-Anabīb: Bayn al-'Ilm wal-Sharī`ah, $2^{\text {nd }}$ ed., (Beirut: Arab Scientific Publishers, 1998), 140-1.

9. Ibid, 139.

10. Martha A. Field, Surrogate Motherhood: Legal and Human Issues, expanded edition, (Cambridge, MA, and London: Harvard University Press, 1990), 1-2.

11. Winkler R and van Keppel M, Relinquishing Mothers in Adoption: Their Long Term Adjustment, in O.B.A. van den Akker, "Psychosocial Aspects of Surrogate Motherhood", Human Reproduction Update, 13, no. 1 (2007): 59.

12. Peter Doskoch, "Which is More Toxic to a Fetus- Antidepressants or Maternal Depression?" NeuroPsychiatry Review, 2, no. 5 (June, 2001).

13. Zayad Ahmad Salamah, 127-9.

14. Muhammad 'A. al-Subḥī, Hukm Isti'jār al-Arḥām, (Alexandria: Dār al-Jāmi'ah al-Jadīdah, 2008), 91-2.

15. "Sah̄ịh" (authentic) Hadīth. Al-Bukhārī, Sahịh al-Bukhārī (Beirut: Al-Maktabah al-'Asriyyah, 2010), (Hadīth no.: 2645), 457.

16. Zayad Ahmad Salamah, 139-140.

\section{References}

Al-Qur'ān al-Karīm 
Aḥmad M. Luṭ̂î Aḥmad, Al-Talqūh al-Ṣanā'̄ Bayna Aqwāl al-Atibbā wa-Arāà alFuqahā, Alexandria: Dar al-Fikr al-Jamā'̄ì, 2006.

Al-Bukhārī, Sahīh al-Bukhārī, Beirut: Al-Maktabah al-'Așriyyah, 2010.

Islam Q\&A, "Is it permissible to put the sperm of the husband and the egg from the wife in the womb of the second wife?" (n.d.), available from: http://islamqa.info/ en/83799, access date: $4^{\text {th }}$ March, 2014.

Islamic Fiqh Council, eighth session held in Makkah Mukarramah between 18 Rabī $^{\circ}$ al-Akhir until Monday 7 Jumada al-Ūla 1405 AH (19-28 January 1985). Available online at: http://www.themwl.org/Fatwa/default. aspx?d=1\&cidi=100\&l=AR\&cid=12, Access date: $20^{\text {th }}$ May, 2010.

Martha A. Field, Surrogate Motherhood: Legal and Human Issues, expanded edition, Cambridge, MA, and London: Harvard University Press, 1990.

Muhammad 'Abdu-Rabbihi M. al-Subhi, Hukm Isti'jār al-Arḥām, Alexandria: Dār al-Jāmi' ah al-Jadīdah, 2008.

O.B.A. van den Akker, "Psychosocial Aspects of Surrogate Motherhood", Human Reproduction Update, 13, no. 1 (2007): 53-62

Peter Doskoch, "Which is More Toxic to a Fetus - Antidepressants or Maternal Depression?" NeuroPsychiatry Review, 2, no. 5 (June, 2001).

Zayad Ahmad Salamah, Atfāl al-Anabìb: Bayn al-'Ilm wal-Sharī'ah, $2^{\text {nd }}$ ed., Beirut: Arab Scientific Publishers, 1998. 